\title{
Towards a Social Theory of the Firm: Worker Cooperatives Reconsidered
}

\author{
Spencer Thompson, University of Cambridge
}

spt36@cam.ac.uk; spen.thompson@gmail.com

$(+44) 7969598056$

Centre of Development Studies

Alison Richard Building

7 West Road

Cambridge, Cambridgeshire

United Kingdom CB3 9DT

\begin{abstract}
This paper argues that the predominant economic theories of the firm neglect the importance of cooperation based on trust and loyalty, and that as a result, their criticisms of worker cooperatives are incomplete. While competence-based theories tend to focus exclusively on coordination and thus fail to acknowledge that the development and application of productive knowledge also involves cooperation, contract-based theories cling to a rigid model of behaviour that does not account for the type of cooperation thus involved. Thus, although contract-based theories denigrate cooperatives for failing to achieve cooperation, cooperatives may in fact be more propitiously situated than conventional firms to achieve the cooperation involved in the development and application of productive knowledge. Meanwhile, although competence-based theories imply that cooperatives are incapable of achieving coordination, cooperatives may in fact be more propitiously situated than conventional firms to achieve coordination without incurring potentially adverse effects on cooperation. This ability, however, may be suppressed by a hostile institutional environment, which biases both the options available to individuals and the way they perceive those options against cooperatives. Although inter-cooperative associations can alleviate this institutional bias, they involve structural and cultural obstacles of their own.
\end{abstract}

Keywords: theory of the firm; cooperation; cooperatives; worker ownership; worker control; hierarchy; inter-cooperation; Japanese firms 


\section{Introduction}

Despite the firm's central role in society and the economy, there is little consensus regarding its purpose, function, and nature. While contract-based theories conceive the firm as an arena of exchange that purports to minimise transaction costs by achieving cooperation, competence-based theories conceive the firm as an arena of production that purports to develop productive capabilities by achieving coordination. These rival schools appear irreconcilable, with attempts to bridge them tending to treat one as subsidiary to the other (e.g. Langlois, 1992; Riordan and Williamson, $1985^{1}$ ). Nevertheless, a common implication of both schools is that cooperative firms are generally inefficient.

This paper will firstly argue that both schools overlook the importance of cooperation based on trust and loyalty. Although competence-based theories are correct that the firm's purpose is to develop and apply productive knowledge rather than to minimise transaction costs, they overlook the cooperation involved in fulfilling that purpose by focusing exclusively on the function of coordination. Meanwhile, although contract-based theories focus on the function of cooperation, they cling to a rigid, individualistic model of behaviour that does not account for the cooperation based on trust and loyalty that is involved in the development and application of productive knowledge. By combining insights from a range of disciplines, the paper will further propose a 'social' theory of the firm in which this 'deep-level cooperation', and the solidaristic behaviour on which it is predicated, take centre stage. A crucial feature of the theory is that, through their adverse effects on behaviour, the bureaucratic organisational structures required for coordination may jeopardise deep-level cooperation. Although an appropriate organisational culture can alleviate this trade-off, it must still be substantiated in organisational structures, giving rise to distributive issues.

The paper will secondly show that this social theory of the firm challenges the dismissal of worker cooperatives ${ }^{2}$ by the predominant theories. Far from failing to achieve cooperation, as alleged by contract-based theories, cooperatives may in fact be more favourably situated to achieve an organisational culture of deep-level cooperation than conventional firms, in which the organisational structures thus required are likely to threaten power-holders. Furthermore, far from failing to achieve coordination, as implied by competence-based theories, cooperatives may in fact be more favourably situated than conventional firms to implement the bureaucratic organisational structures that may be required for coordination (namely complex divisions of labour and hierarchical management systems) without compromising deep-level cooperation, because worker control can counteract their adverse behavioural effects. However, this ability may be suppressed by a hostile institutional environment, which biases both the options that individuals face and the way they perceive those options against cooperatives. Inter-cooperative associations can resist this institutional bias, but face their own structural and cultural obstacles.

The argument that worker cooperatives may be able to implement complex divisions of labour and hierarchical management systems on more favourable terms than conventional firms is similar to Valentinov's (2007) argument that agricultural cooperatives are capable of garnering the

\footnotetext{
${ }^{1}$ Some notable exceptions include Kogut and Zander, 1992, 1996; Nooteboom 1992, 2009.

${ }^{2}$ I henceforth refer to worker cooperatives as simply 'cooperatives' or 'cooperative firms'. In this regard, it is important to note that there are in fact a diversity of other types of cooperative (consumer, financial, etc.), which, although perhaps relevant, are not the subject of this paper.
} 
benefits of family-based farms in terms of trust and loyalty whilst also achieving the economies of scale (which can be conceived as a function of coordination) foregone by those farms. It is, moreover, especially relevant to developing countries: even if advanced economies are shifting (or have already shifted) away from Taylorism and Fordism, industrialisation has historically held the key to economic development ${ }^{3}$ (Reinert, 2007).

\section{Towards a Social Theory of the Firm}

\subsection{The (Economic) Purpose of the Firm}

Following Ronald Coase's seminal 1937 article, contract-based theories maintain that the purpose of the firm is to minimise the "transaction costs" of market exchange, which pertain to the opportunistic behaviour resulting from asymmetric information (e.g. Alchian and Demsetz 1972; Williamson, 1975, 1985) ${ }^{4}$. The firm fulfils this purpose by optimally allocating and enforcing rights over output or decisions that are otherwise non-contractible, thus achieving cooperation. In contrast, competence-based theories maintain that the purpose of the firm is to develop "dynamic capabilities", which denote the capacity for learning and innovation (e.g. Teece, 1982; Penrose, 1959; Nelson and Winter, 1982). The firm fulfils this purpose by productively combining skills and resources, thus achieving coordination.

Which of these accounts is accurate? On the one hand, Williamson (1985, Chapter 9) has astutely pointed out that Adam Smith's (1776) theory of the division of labour (which, according to Langlois and Foss [1999] and Foss [1997], is the foundation of contemporary competence-based theories) does not provide a sound answer to the question that Coase famously posed in 1937 namely, why production is integrated within a firm rather than performed over the market ${ }^{5}$. Contract-based theories attempt to answer this question, and thus offer a coherent explanation for the purpose of the firm that is supposedly lacking in competence-based theories, by invoking the cooperation problems associated with asymmetric information and the contractual means of overcoming them. By thus focusing on asymmetric yet hypothetically tradable information ${ }^{6}$, however, contract-based theories envisage the firm to be a mere constellation of market-like

\footnotetext{
${ }^{3}$ There are sound theoretical reasons that explain this empirical fact relating to the unique characteristics of manufacturing that are lacking in, say, commodities and (most) services. These include: increasing returns; scope for synergies and technological upgrading; production for exports and thus foreign exchange; the tendency for increases in productivity to be translated into higher wages rather than lower prices; the ability to absorb low-productivity labour from the rural sector; and so on.

${ }^{4}$ Not all contract-based theories of the firm explicitly appeal to transaction costs. However, they can all be interpreted in the transaction-cost framework, because they are all concerned with addressing the constraining the opportunistic behaviour that results from asymmetric information, whether in terms of workers free-riding on each other's effort (e.g. Alchian and Demsetz, 1972) or investment partners making unproductively strategic investment decisions (e.g. Grossman and Hart, 1986; Hart and Moore, 1990). Indeed, as Dahlman (1979: 148) argues, all incentive problems - and therefore all transaction costs - can be reduced to matters of imperfect, and especially asymmetric, information.

${ }^{5}$ Another way of phrasing this question is: why do workers sign employment contracts, which allow employers to control the workplace, rather than sell their labour (or its fruits) as independent contractors (or merchants)? ${ }^{6}$ It was Coase (1937: 92), after all, who claimed that "[w]e can imagine a system where all advice or knowledge was bought as required".
} 
exchanges (a "nexus of contracts"7; e.g. Alchian and Demsetz, 1972), or at least fail to explain why it should be anything more than that (e.g. Williamson, 1975; see Hodgson, 1999: 205). This reductionist definition, despite being inconsistent with the activities of real-life businesses ${ }^{8}$, in fact sidesteps Coase's question - the very question that Williamson posed to Adam Smith - by maintaining that there is in fact no such as thing as the firm, at least in the sense of an institution that is qualitatively different from the market.

By contrast, competence-based theories focus on productive knowledge, which is often tacit, embedded in groups and practical settings, or not fully developed, and therefore not tradable even in principle (Knight, 1921; Penrose, 1959; Teece, 1982, 1986). Indeed, according to competencebased theories, the non-tradability of productive knowledge is precisely why it must be harnessed within the collective organisation of the firm, rather than through market-like exchange - it is "the very essence of capabilities/competences" (Teece and Pisano, 1994: 540). The firm is thus afforded 'emergent properties', because the productive knowledge developed and applied by the combination of individuals cannot be reduced to the knowledge of those individuals (Winter, 1982: 76, 1988: 170; Dosi and Marengo, 1994; Kogut and Zander, 1992: 384).

\subsection{The (Social) Function of the Firm}

Although competence-based theories are therefore correct that the purpose of the firm is to develop and apply productive knowledge, they have not provided an adequate account of precisely how that purpose is fulfilled. In particular, by focusing primarily on the function of coordination, they fail to sufficiently heed the fact that the development and application of productive knowledge especially the non-tradable forms of productive knowledge with which they are concerned - also requires cooperation ${ }^{9}$ (Polanyi, 1958, 1966; Nooteboom, 2009; Osterloh and Frey, 2000). Thus, while stating that competence-based theories surpass their contract-based counterparts by acknowledging that "the competence underlying productive, allocative and strategic decisions is tacit and generated through experience of particularity and idiosyncrasy, particularly in social settings", Foss (1993: 134, emphasis added) goes on to acknowledge that it is precisely "the social component of the competences of the firm" that is undeveloped in competence-based theories. As a result of this neglect, the competence-based definition of the firm collapses into a mere "pool of intangible resources" (Penrose, 1959) or a "repository of productive knowledge" (Winter, 1988) - a 'black box' of learning and innovation that fails to improve on the reductionist definition offered by contractbased theories.

Contract-based theories focus on the function of cooperation, but assume that behaviour is universally characterised by market-like transactions between instrumentally-motivated

\footnotetext{
${ }^{7}$ This phrase is found throughout contract-based theories, including Jensen and Meckling, 1976: 311; Fama and Jensen, 1983: 322; Fama, 1980; Hart, 1989: 1763-5; Moore, 1992; Alchian and Demsetz, 1972: 777-8.

${ }^{8}$ See Cohendet and Llerena, 2005; Walker and Weber, 1984; Monteverde and Teece, 1982; Jacobides and Winter, 2005: 400; Argyres and Liebeskind, 1999; Argyres and Mayer, 2004; Madhok, 2002. See Carter and Hodgson, 2006 for a review of these studies.

${ }^{9}$ Nelson and Winter (1982) attempt to integrate cooperation into their concept of routines, which serve to not only coordinate production but also to establish a "truce" between different members of the firm. However, exactly how relationships are governed is not spelled out. See Cohendet and Llerena, 2003; Nooteboom, 1992, 2009: 21; Becker, 2004; Teece and Pisano, 1994.
} 
"contractual men" (what I call 'individualistic behaviour'), and consequently that cooperation is achieved only by rearranging the opportunities and incentives facing individuals (e.g. Williamson, 1985, Chapter 2). This 'surface-level cooperation' is insufficient when it comes to non-tradable knowledge, which, unlike tradable information, cannot be assigned property rights or monetary value $^{10}$ (Osterloh and Frey, 2000; Teece and Pisano, 1994: 539). Although this is most obvious in cases requiring initiative, teamwork, and innovation, even the most 'deskilled' tasks contain "some residual element of discretion" that cannot be efficiently contracted or monitored (Fox, 1974: 19-20, 149; Bendix, 1963: 241). This is evidenced by the fact that strict obedience to contracts ('work-torule') is a form of industrial sabotage (Crozier, 1964: 189). Thus, if the firm exists to develop and apply productive knowledge, its "very nature and rationale" involves achieving cooperation on a 'deeper level' ${ }^{11}$ (Simon, 1991: 33). The firm can therefore be defined as a social institution dedicated to production.

\subsection{Behaviour and Cooperation}

What, then, is this 'deep-level' cooperation, and how does the firm achieve it? To answer this question, we must first distinguish between the cognitive and relational aspects of behaviour, which, due to their interdependency, entail two distinct 'behavioural modes': as envisaged by contract-based theories, behaviour can be individualistic, characterised by market-like transactions between instrumentally-motivated individuals, but on the other hand, behaviour can also be solidaristic, characterised by social relationships (Blau, 1964: 91; Simmel, 1964 [1917]) between substantively-motivated ${ }^{12}$ individuals (Weber, 1978 [1922]: 85-6). This duality is evident in the work of Adam Smith, who, despite referring repeatedly in The Wealth of Nations to "a certain propensity in human nature... to truck, barter, and exchange" and assuming that "the butcher, the brewer, [and] the baker" all perform their jobs out of purely instrumental motivation (1904 [1776], Book I, Chapter 2, paras. 1 and 2), begins The Theory of Moral Sentiments with the statement: "How selfish soever man may be supposed, there are evidently some principles in his nature, which interest him in the fortune of others, and render their happiness necessary to him, though he derives nothing from it except the pleasure of seeing it" (1790 [1759], Section I.I.1).

After establishing these behavioural modes, we can generalise that whereas surface-level cooperation is achieved through organisational structures (such as property rights, pay schemes, and monitoring systems), which constrain individualistic behaviour, deep-level cooperation is achieved through an organisational culture, which enables solidaristic behaviour. An organisational culture

\footnotetext{
${ }^{10}$ As Nooteboom (2009) points out, the literature on 'communities of practice', which attempts to explain how specialised knowledge is formed and disseminated, is instructive in this regard: it appreciates that cooperation cannot be taken for granted (as in competence-based theories), but nor can it be achieved through predetermined, self-interested agents (as in contract-based theories). See Brown and Duguid, 1991, 2000; Wenger, 1998; Lave and Wenger, 1991; Wenger, McDermott, and Snyder, 2002; Goffin and Koners, 2011; Schmidt and Hunter, 1993.

${ }^{11}$ This is in contrast to Williamson's (1996: 55) claim that that deep-level cooperation, which is "sometimes held to be the main purpose of economic organization, especially by noneconomists", is "auxiliary" to the "core purpose" of minimising transaction costs by constraining opportunism.

${ }^{12}$ Note that I am not using the phrase 'substantive rationality' in the same sense as Simon (1976: 130-1), who in fact used it to describe what I have called 'instrumental rationality'. Simon (ibid.) contrasted his "substantive rationality" with "procedural rationality", which is actually closer to my usage of the phrase.
} 
can be defined as a set of cognitive frames and social norms shared across the organisation (March and Simon, 1958: 129). In particular, the firm must cultivate a cognitive frame of organisational loyalty, such that individuals identify with the firm to the point of subordinating their immediate interests to the goals of the firm and "accept[ing]... responsibilities beyond any specific contracted function" (Parson and Smelser, 1956: 116; see also Schein, 1992; Smirchich, 1983). It must also cultivate a social norm of trust, such that members expect that others will act in accordance with organisational loyalty (Kogut and Zander, 1992; Islam and Zyphur, 2006; Deal and Kennedy, 2000). Just as individual behaviour involves cognitive and relational aspects, organisational structures and organisational culture can be respectively conceived as the cognitive and relational aspects of organisational behaviour.

Organisational structures and organisational culture, however, affect behaviour in a more fundamental way than simply acting on whatever mode of behaviour (individualistic or solidaristic) happens to prevail; they also influence which mode prevails in the first place (Argyris, 1964; Moschandreas, 1997; Bowles, 1985). Contrary to the rationalist methodology of contract-based theories, individuals are not fully determined prior to any institutional realities. Rather, to deal with their cognitive limitations ("bounded rationality"), they rely on institutions such as the firm to "constitute" their behavioural foundations ${ }^{13}$ (Simon, 1957, 1991; Chang and Evans, 2005; Hodgson, 2002; Berger and Luckmann, 1967). On the cognitive side, an emphasis on social approval and reputation can activate intrinsic work motivations, just as an emphasis on material rewards and punishments can crowd them out by propagating an instrumental perception of work (Deci, 1971, 1975; Deci and Ryan, 1985) ${ }^{14}$. On the relational side, leaving room for job discretion can facilitate reciprocity that engenders norms of trust, just as minimising discretion through extensive specification and intensive enforcement of responsibilities can configure the employment relation to be a mere transaction (Akerlof, 1982; Fox, 1974).

\subsection{The Trade-off between Cooperation and Coordination}

Although deep-level cooperation is "the very nature and rationale of organization" (Simon, 1991: 33), production also requires coordination, as competence-based theories have stressed. Furthermore, as demonstrated by game theory, it is reasonable to presume that problems of coordination will apply even if cooperation has already been achieved. This implies that, at least for advanced technologies, 'bureaucratic' organisational structures like complex divisions of labour and hierarchical management systems may be required for the purpose of coordination ${ }^{15}$, even if

\footnotetext{
${ }^{13}$ Contract-based theories in fact allude to this behavioural endogeneity, but only parenthetically (e.g. Williamson, 1975: 98-9; Alchian and Demsetz, 1972: 790). This is despite the fact that Williamson (1985, Chapter 2) assumes from the outset that "contractual man" is boundedly rational, which implies that he is not necessarily opportunistic (see Foss, 2003).

${ }^{14}$ For meta-studies that confirm the 'crowding out' effect, see Rummel and Feinberg, 1988; Wiersma, 1992; Tang and Hall, 1995. Cameron and Pierce (1994) and Eisenberger and Cameron (1996) challenge these metastudies, but are rebuffed by Deci, Koestner, and Ryan (1999a, 1999b).

${ }^{15}$ This proposition has been contested by some radical authors, such as Marglin (1974), who argues that more egalitarian divisions of labour and management systems would have been equally if not more efficient than the bureaucratic divisions of labour and management systems that characterised the factory system, even for the same underlying technologies.
} 
cooperation has been achieved on the deep-level through organisational culture (Pagano 1991: 138, footnote 1).

Given the endogeneity of behaviour, however, this presents somewhat of a predicament: bureaucratic organisational structures, implemented for the purpose of coordination, might stimulate individualistic behaviour, thus undermining deep-level cooperation. Indeed, this trade-off may be so critical that it competes with, or at least supplements, other answers to the perennial question of why firms do not expand indefinitely, such as the proliferation of 'bureaucratic costs' and other sources of scale diseconomies (Coase, 1937: 394-8; Williamson, 1985, Chapter 6; Mahoney, 1992). As the firm expands, and as production becomes more complex, the trade-off becomes more acute, because coordination becomes increasingly essential while organisational culture becomes increasingly difficult to maintain (Kogut and Zander, 1996: 511-2; Nooteboom, 2009: 15). The range of theoretical and empirical literatures showing that the size of the firm is correlated with either the degree of worker alienation (e.g. Blauner, 1964, Indik, 1963; Ingham, 1970) or the fomentation of class consciousness (e.g. Phillips, 1985; Kerr and Siegel, 1954; Shorter and Tilly, 1974), to the neglect of organisational trust and loyalty, are germane.

\subsection{Cultural Contingency and Structural Consistency}

To more clearly understand the cooperation/coordination trade-off requires a more nuanced model of how organisational structures and organisational culture influence behaviour than the one proposed in Section 2.3. First of all, the behavioural impact of organisational structures is mediated by organisational culture. As Durkheim (1893) argued in relation to his seminal theory of "anomie", and as empirical work in economics and social psychology has confirmed (see Akerlof and Kranton, 2008), what matters for behaviour is not whether a certain organisational structure prevails, but how it is interpreted by workers with respect to the goals and relations they share with the firm. The adverse behavioural effects of bureaucratic organisational structures can therefore be averted with the appropriate organisational culture. This possibility is borne out in Japanese firms, which appear to enjoy the benefits of bureaucratic organisational structures like complex divisions of labour and hierarchical management systems in terms of coordination while also featuring a remarkable degree of deep-level cooperation (Lincoln and Kalleberg, 1990; Gjerding, 1992; Aoki, 1990). This feat has clearly been made possible by an organisational culture that emphasises loyalty and conformity, regularly expressed in symbols and rituals (Rohlen, 1974).

The notion of 'cultural contingency' has led some authors, most famously Hofstede (2001), to take an essentially culturalist stance, maintaining that the behavioural impact of any given organisational structure is determined by exogenous cultural traits (e.g. Vroom, 1964; Blood and Hulin, 1967; Turner and Lawrence, 1965), a proposition which appears to find some empirical support (Gallie, 1978; Maurice, Sorge, and Warner, 1980; Brossard and Maurice, 1976). The remarkable organisational culture of Japanese firms, for example, has been attributed to the unique features of Japanese culture, such as the high value placed on loyalty by its unique variety of Confucianism (e.g. Abegglen, 1958; Nakane, 1970; Morishima, 1982). However, while organisational culture mediates the behavioural impact of organisational structures, it must also be grounded in organisational structures, because individuals will not espouse a cognitive frame or relational norm if 
it is inconsistent with their everyday experience ${ }^{16}$ (Kogut and Zander, 1996). Chang (2008, Chapter 9) has therefore shown that the trait of loyalty only became apparent in Japanese society after organisational structures like welfare services and lifetime employment were introduced. By corroborating the notion of the firm as a family, these organisational structures offset, and perhaps even reverse, the adverse behavioural effects of bureaucratic organisational structures. In fact, Japanese firms go further by altering those structures themselves: job rotation and work groups are added to the division of labour (Gjerding, 1992: 106; Aoki, 1990), while managerial hierarchies are based on seniority ('nenko') and compressed in remunerative terms (Lincoln and Kalleberg, 1990: 95; Clark, 1979; Cole, 1971, 1979). That the organisational structures of Japanese firms substantiate their envied organisational culture is corroborated by the fact that they have been adopted across the globe, even amidst cultures that would appear unfavourable to such a system (Dore, 1973; Gjerding, 1992).

Following the thesis of an assortment of Marxian and Weberian commentators (e.g. Edwards, 1979; Edwards, Gordon, and Reich, 1975; Burawoy, 1983), not to mention the work of authors such as Bourdieu, Foucault, and Gramsci, critics of Japanese firms consider these distinctive organisational structures to represent a means of "bureaucratic control", whereby managers legitimise their position vis-à-vis workers by distracting attention from the real distribution of power ${ }^{17}$ (e.g. Grenier, $1988^{18}$ ). In reality, however, the requirement of structural consistency creates somewhat of a 'distributive dilemma' for power-holders, who may be required to revise the very organisational structures that sustain their power - namely the division of labour, the management system, and the structure of ownership and control - in order to achieve deep-level cooperation. Although cultural manipulation can partially alleviate this dilemma, the fates of managerial ideologies throughout the ages show that, ultimately, managers cannot have their cake (deep-level cooperation) and eat it too (by retaining power) (Fox, 1974). Indeed, numerous commentators agree that Japanese firms are in effect run in the interests of their workers, pointing to their participatory system of decision-making ('ringi') and their sophisticated bonus system (e.g. Aoki, 1988, Chapter 5; 1990: 14-22; Yoshino, 1971; Vogel, 1975; Urabe, Child, and Kagono, 1988). This power constraint may explain why international implementations of Japanese-style quality circles generally failed to elicit the type of behaviour observed in Japan - they permitted only informal suggestions rather than real participation in decision-making, with managers retaining ultimate control (Hill, 1986; Bradley and Hill, 1987; Fucini and Fucini, 1990).

\section{Worker Cooperatives Reconsidered}

\subsection{Managerial Hierarchies and Cooperatives}

The 'social' theory of the firm proposed in Section 2.1 can be expediently applied to cooperative firms, which both of the predominant schools have generally dismissed as inefficient. In particular, both schools emphasise the importance of hierarchical management systems, which they

\footnotetext{
${ }^{16}$ Geertz (1973) analogously argued that "cultural systems" must always be rooted in "social systems".

${ }^{17}$ Indeed, given the influence of Japanese work practices in Western countries, the 'critical management' literature can be seen as an extension of this criticism (e.g. Willmott, 1993; Knights and Willmott, 1987, 1989; Parker, 2002).

${ }^{18}$ See also Rinehart, Huxley, and Robinson, 1997; Parker and Slaughter, 1988; Hanappi-Egger, 1996.
} 
associate with the capitalist firm. However, they diverge in a subtle yet consequential way over precisely why managerial hierarchies are required, and why they are associated with the capitalist firm.

Contract-based theories maintain that managerial hierarchies are required to achieve surface-level cooperation by constraining the opportunistic behaviour that would otherwise result from a complex division of labour. First, managers can monitor, reward, and punish workers, who would otherwise free-ride on each other's efforts ("shirk") due to the asymmetries of information inherent in joint labour ("team production") (Williamson, 1975; Alchian and Demsetz, 1972; Holmstrom, 1982). Second, managers can authoritatively make investment decisions that would otherwise be subject to inefficient rent-seeking ("hold-up") due to the inextricability of assets from the production process ("asset specificity") (Grossman and Hart, 1986; Hart and Moore, 1990; Klein, Crawford, and Alchian, 1978) ${ }^{19}$. Competence-based theories, on the other hand, maintain that managerial hierarchies are required to achieve the coordination that would otherwise be lacking in a complex division of labour. In particular, by facilitating specialisation in the management function, managerial hierarchies can efficiently control the flow of information and the allocation of skills and resources between stages of production, taking into account risk, uncertainty, and change (Chandler, 1977, 1990; Chandler and Daems, 1981; Simon, 1962; Knight, 1921). They can also provide symbolic leadership in order to ensure that deep-level cooperation is channelled productively (Nelson and Winter, 1982).

Chandler and Williamson, perhaps the most outspoken advocates of the capitalist firm in their respective schools, both downplay the distinction between the contract-based and competence-based rationales for managerial hierarchy, even to the point of citing each other (Chandler, 1992; Chandler and Daems, 1981: 217; Williamson, 1985, Chapter 11). According to the theory outlined above however, the rival justifications of managerial hierarchy are not merely 'two sides of the same coin'. Although they may overlap, with certain organisational structures and organisational cultures purporting to achieve both, cooperation and coordination are separate objectives, with distinct implications for organisation ${ }^{20}$.

Turning firstly to contract-based theories, the case for managerial hierarchy based on surface-level cooperation leads almost axiomatically to the conclusion that workers cannot

\footnotetext{
${ }^{19}$ Although contract-based theories that focus on cooperation problems in investment rather than work do not explicitly mention managerial hierarchies, they can still be interpreted as assuming that managerial hierarchies are required to achieve surface-level cooperation because they essentially envisage a 'classical' firm whereby ownership and management are indistinct. According to Grossman, Hart, and Moore, for instance, the hold-up problem can be mitigated by granting "residual rights of control" to one of the parties, who will then hire the other party's assets. These control rights are "residual" because they authorise their owner to control the use of the other party's asset beyond any contractual obligations. They are therefore equivalent to what Coase (1937) called "direction", which he equated with managerial hierarchy. The same qualification applies to the neoclassical literature on the 'Labour-Managed Firm' - note that, although they compare capital- and labour-owned firms, they nevertheless label their representative firms as capital-and labour-managed.

${ }^{20}$ Indeed, despite his lip-service to Chandler's account, Williamson's $(1975,1985)$ dismissal of egalitarian work modes is fully predicated on their alleged inability to achieve surface-level cooperation: in his analysis, they perform proficiently on dimensions of "product flow" and "assignment", which essentially refer to the coordination of production, falling short only in the category of "incentives", including shirking, equipment maintenance, and investment. Contrariwise, although Chandler mentions Williamson's transaction-cost arguments, they are in no way necessary for his story of coordination to remain coherent.
} 
own/control the firm, because non-worker ownership/control is an intrinsic part of how managerial hierarchies are supposed to achieve cooperation (see Jensen and Meckling, 1979). Indeed, Coase (1937) equated managerial hierarchies (which he saw as the defining feature of the firm in general) with the capitalist firm. For instance, the most efficient way to incentivise managers to monitor workers is to award them the property rights to the 'residual', which represents the product left over after all individually contractible returns have been paid (Alchian and Demsetz, 1972; Barzel, 1987). Workers, however, could not be thus incentivised, because they would merely free-ride on each other's monitoring in addition to their work. Likewise, worker-owners could not efficiently implement rewards and punishments on themselves, because ex-post they would always have an incentive not to incur debt or to waste output ("break the budget"), which may be required for an optimal incentive scheme (Holmstrom, 1982). Meanwhile, a series of models based on the 'LabourManaged Firm' have asserted that worker-ownership incurs a range of perverse investment incentives due to the bundling of wealth and work ${ }^{21}$ (see Bonin and Putterman, 2001). What makes ownership by capital efficient in these models is precisely that non-workers, whose wealth is not tied up in their job, make investment decisions - in other words, that investment decisions are made through managerial hierarchies.

Is the contract-based rationale for managerial hierarchy valid? On the one hand, the notion that managerial hierarchies (coupled with capitalist ownership) are required to achieve surface-level cooperation can be disputed on the grounds that cooperatives may be able to attain surface-level cooperation without managerial hierarchies. For instance, worker-management may entail less asymmetry of information and costs of bureaucracy than hierarchical management (e.g. Aoki, 1984; Fitzroy and Kraft, 1986; Putterman, 1984), while worker-ownership may entail superior incentives for work and investment than non-worker ownership (e.g. Eswaran and Kotwal, 1984; Blinder, 1990; Matrix Evidence, 2010). More important, however, is the assumption that individualistic behaviour prevails universally and unconditionally, and therefore that cooperation is achieved only on the surface level. In reality, managerial hierarchies may induce (or at least reinforce) that very behaviour, precluding the solidaristic behaviour that enables deep-level cooperation ${ }^{22}$ (see Section 2.1.3). In any case, due to the distributive dilemma, capitalist firms will be severely limited in substantiating an organisational culture of deep-level cooperation, and may therefore rely on managerial hierarchies to achieve surface-level cooperation (e.g. Marglin, 1974; Braverman, 1974).

By contrast, non-hierarchical management and worker ownership/control may not only contribute to solidaristic behaviour and deep-level cooperation directly, but also allow decisionmakers (namely worker-members) to enjoy the productive benefits of deep-level cooperation. Indeed, numerous studies have found higher levels of trust and loyalty in cooperatives than in comparable capitalist firms (Frohlich et al., 1998; Estrin, Jones, and Svejnar, 1987; Gherardi and Masiero, 1990). Crucially, the incidence of deep-level cooperation precludes the need for managerial hierarchies to achieve surface-level cooperation (Valentinov, 2004). Indeed, worker-owned and -

\footnotetext{
${ }^{21}$ For instance, worker-owners may be reluctant to expand membership because doing so would dilute the value of their shares; they may shun capital-intensive investments that threaten their jobs; they may behave risk-aversely due to their wealth being undiversified; or they may refuse to make investments that are only expected to yield returns after they have retired.

${ }^{22}$ That this behavioural effect is mediated by organisational culture is a moot point in this case, because an organisational culture achieving deep-level cooperation would obviate the need for managerial hierarchies to achieve surface-level cooperation in the first place.
} 
managed firms have been empirically shown to feature less managerial supervision than traditional firms, in part due to the prevalence of 'mutual monitoring' ${ }^{23}$ (Russell 1985; Weitzman and Kruse, 1990; Bonin, Jones, and Putterman, 1993).

If the contract-based rationale for managerial hierarchy is unfounded, what about the competence-based rationale? Some radical authors dispute the notion that managerial hierarchies are required to coordinate production, contending that less complex divisions of labour, accompanied by less hierarchical management systems, are feasible for any given technology (Marglin, 1974). They further contend that 'de-skilled' divisions of labour are not more productive, prevailing only because they justify the role of managers (Braverman, 1974). However, while maximally partitioned divisions of labour are likely to be inefficient, as Adam Smith (1776) himself acknowledged (for instance, because they stifle teamwork, learning, and innovation), some degree of specialisation - and thus managerial hierarchy - is likely to be required for coordination, as mentioned above.

Unlike the contract-based rationale for managerial hierarchy, however, the competencebased rationale does not disqualify the cooperative firm. Indeed, Chandler appears to associate managerial hierarchies with the capitalist firm merely due to historical happenstance ${ }^{24}$ (see also Langlois, 2007). It may be assumed that cooperatives are precluded from implementing complex divisions of labour and managerial hierarchies because they espouse egalitarian principles. However, ownership and control by labour does not necessarily entail functional equivalence or equal pay among the workforce; it is possible in theory, and common in practice, for worker-owners to democratically consent to complex divisions of labour and to elect managers to coordinate that division of labour if they perceive (net) economic benefits of doing so ${ }^{25}$ (Ben-Ner and Jones, 1995; Russell, 1985; Vogt, 1996: 40-1). Such managers would exercise only delegated (or "formal") rather than ultimate (or "real") authority (Aghion and Tirole, 1997); as envisaged by competence-based theories, they would essentially be just another cog in the division of labour (Knight, 1921; Langlois and Cosgel, 1993).

In fact, when deep-level cooperation is considered, worker-owned firms may be more propitiously situated to implement managerial hierarchies (along with complex divisions of labour) for the sake of achieving coordination than conventional firms. As explained in Section 2.4, a potential trade-off exists between coordination and deep-level cooperation, which can be alleviated by an organisational culture that tolerates bureaucratic organisational structures. However, that organisational must still be substantiated in organisational structures; and if the division and labour and the management system must be bureaucratic for the purpose of coordination, structural

\footnotetext{
${ }^{23}$ Jensen and Meckling (1979: 485) point out that mutual monitoring entails a collective action problem in itself. This, however, is precisely the point. Workers will only monitor each other if they are substantively motivated to do so (due to loyalty to the firm), and if they expect enough of their co-workers to do so (due to trust) - that is, if deep-level cooperation prevails.

${ }^{24}$ Although he does point out that innovations in steam power and electricity required exceptionally capitalintensive forms of production, this is an explanation for why capitalists rather than workers do own/control the firm, not why they should - unless, of course, one takes a contract-based perspective.

${ }^{25}$ If it seems unfeasible for workers to elect managers without sacrificing ultimate control, consider that shareholders in capitalist corporations essentially do the same - although managers are delegated with the authority to initiate and implement decisions ("decision management"), shareholders nevertheless retain the authority to ratify and monitor decisions ("decision control") (Fama and Jensen, 1983).
} 
consistency must be achieved in the realm of ownership and control - that is, the system of governance. The distributive dilemma will therefore prevent capitalist firms from overcoming the cooperation/coordination trade-off, as any managerial hierarchies they implement for the purpose of coordination are likely to stimulate individualistic behaviour, thus bringing to fruition the need for hierarchy to achieve surface-level cooperation. This is perhaps why Williamson and Chandler, who primarily analyse the capitalist firm, seem to believe that their competing rationales are merely expressing two sides of the same coin - in capitalist firms, the coordination and cooperation roles of managerial hierarchies are indeed inseparable.

Cooperatives, by contrast, do not face the distributive dilemma, and so contain the potential to mitigate the cooperation/coordination trade-off by separating the dual functions of managerial hierarchy: with deep-level cooperation achieved through participation in governance, coordination can be achieved through managerial hierarchies in the workplace ${ }^{26}$ (Fox, 1974, Chapter 2; Kaswan, 2013; Pateman 1970: 69-72 ${ }^{27}$ ). Furthermore, because managers are elected by workers (they are "representative") and do not purport to achieve cooperation but only coordination (they are not "punishment-centred"), their adverse behavioural effects are likely to be diminished (Gouldner, 1954); as Marx (1959 [1894], Chapter 23, para. 48) recognised, "In a co-operative factory the antagonistic nature of the labour of supervision disappears, because the manager is paid by the labourers instead of representing capital counterposed to them." ${ }^{28}$

The Mondragón group of cooperatives in the Basque country is perhaps the foremost example of combining worker ownership and control with complex divisions of labour and hierarchical management systems ${ }^{29}$. It is clear that Mondragón has achieved coordination, as

\footnotetext{
${ }^{26}$ Indeed, Ouchi (1980) argued that because some organisations (what he called "clans") achieve coordination through managerial hierarchies but rely on other organisational structures (in this case the governance system) to achieve deep-level cooperation, Williamson's (1975) dichotomy between "markets and hierarchy" was incomplete.

${ }^{27}$ Pateman argued that "full participation" in governance (what she called the "high level") could significantly affect democratic attitudes and abilities even when participation in the workplace (the "low level") was only "partial".

${ }^{28}$ It has been claimed, most forcefully by Hansmann (1988, 1990, 1996; see also Webb, 1891; Webb and Webb, 1920) that worker governance is itself a source of inefficiency, not least due to the intensive and extensive processes that it entails. Be that as it may, I have argued that it also facilitates deep-level cooperation - and the preservation of this deep-level cooperation amidst bureaucratic structures in the workplace - in a way that is not available to firms with conventional power structures. Spear (2004) and Cornforth (2004), meanwhile, have outlined the agency problems associated with maintaining hierarchical management systems in member-based firms, including a smaller skill-based from which to elect board representatives; a multiplicity of organisational goals, including non-quantifiable ones, by which to evaluate managerial performance; and a lack of disciplinary pressure from stock and managerial markets. However, these problems are largely a symptom of a hostile institutional environment, and can therefore be addressed through institutional innovations such as the inter-cooperative associations discussed in Section 3.2. In any case, there are also reasons why worker control may more effectively deal with managerial agency problems than capitalist control. Whereas capitalist owners must judge the quality of management from afar, and anyway have little incentive to monitor managers if shareholding is liquid and dispersed, workers are in daily, face-to-face contact with managers and, given the bundling of their wealth and their job, have a strong interest in ensuring that managers perform (Putterman, 1984). At any rate, managers may themselves be influenced by the firm's organisational culture and so behave solidaristically, as Spear (2004: 46) acknowledges.

${ }^{29}$ In large part, this is a reflection of the founder, Don Jose María Arizmendiarrieta, who had a remarkable appreciation for the competence-based rationale for managerial hierarchies (MacLeod, 2000: 70-4, 84-7;
} 
evidenced by its vast size (it was the seventh-largest company in Spain in 2012; Mondragón Corporation, 2012); its high quality of management relative to conventional firms operating in the same sectors (Abando, Gallartegi, and Rodriguez, 2007); its operation in a multiplicity of sectors; and its exceptional capacity for innovation (Lopez, Lopez, and Larrañaga, 2009: 51; Bakaikoa, Agirre, and Errasti, 2008). Surveys published by Bradley and Gelb in 1981 showed that the Mondragón cooperatives had also achieved deep-level cooperation, as workers reported greater levels of job control, participation, and work motivation; identified more strongly with their firm; and maintained higher-trust and more consensual relationships with their colleagues and managers than workers in capitalist firms with similar divisions of labour and management systems. As with Japanese firms, many observers of Mondragón have attributed this feat to the exceptionally solidaristic features of Basque culture (e.g. Logan, 1979; Hansmann, 1996, Chapter 6; Oakeshott et al., 1977). Following the argument of this section, however, it would appear that Mondragón has in fact "created as distinctive organizational culture" (Whyte and Whyte, 1988: 281, emphasis in original) through its systems of cooperative governance (Greenwood and Gonzalez Santos, 1992: 154).

The ability of cooperatives to transcend the cooperation/coordination trade-off by avoiding the distributive dilemma is perhaps why Marx, other radicals, and even the unionist movement have historically maintained an ambivalent attitude towards them (e.g. Marx, 1970 [1875]). On the one hand, cooperatives represent a feasible way of managing complex production processes without capitalist employers $^{30}$ (Egan, 1990). On the other hand, as an inherent contradiction of capitalism, the distributive dilemma is implicated in the development of class consciousness. By overcoming it, and potentially eliminating class distinction within the enterprise altogether, cooperatives may therefore impede the revolution, for instance displacing the role of trade unions. Indeed, if workers elect managerial hierarchies and consent to alienating workplaces, all the while espousing an organisational culture of deep-level cooperation, they may essentially be engaging in 'selfexploitation' by acting "as their own capitalists"31 (Jossa, 2005: 14), thus "reproduc[ing]...all the shortcomings of the prevailing system" (Marx, 1959 [1894]: 431) - a system that, it should not be forgotten, Marx admired for its productive capacity. Not surprisingly, all of these criticisms have been directed towards Mondragón (Kasmir, 1996). In short, both the praise and the scorn that Marxists have directed towards cooperatives demonstrate their productive power.

Azurmendi, 1985: 421; Whyte and Whyte, 1988: 253, 257). Indeed, Arizmendiarrieta reckoned that democratic governance would allow cooperatives to implement managerial hierarchies and complex divisions of labour while maintaining deep-level cooperation, thus affording "all the means available to capitalistic corporations plus the added moral force of cooperative principles" (MacLeod, 2000: 85). In this manner, he believed that cooperatives could not only compete with capitalist firms, but also surpass them, particularly through their superior flexibility in adapting to shifts in technology (ibid.: 88).

${ }^{30}$ In his inaugural address to the First International, for example, Marx (1864, para. 13, emphasis added) stated that cooperatives "have shown that production on a large scale, and in accord with the behests of modern science, may be carried on without the existence of a class of masters employing a class of hands...and that, like slave labor, like serf labor, hired labor is but a transitory and inferior form, destined to disappear before associated labour...". He therefore considered cooperatives to be a "transforming force" (1867, Section 5, para. 2) in that they "represent within the old form the first sprouts of the new" (1959 [1894], Chapter 27, para. 17). Engles (1989 [1880]: 43) likewise opined that cooperatives have "given practical proof that the merchant and the manufacturer are socially quite unnecessary".

${ }^{31}$ See also Paranque and Willmott, 2014. 


\subsection{Explaining the Infrequency of Cooperatives}

If cooperatives indeed possess a unique advantage in implementing bureaucratic organisational structures, as I have suggested, the question arises as to why they are conspicuously rare in sectors requiring complex divisions of labour and hierarchical management systems (Ben-Ner, 1988a; Dow, 2003; World Co-operative Monitor, 2013), having been concentrated in agriculture and non-standardised services since their emergence in the nineteenth century (Zamagni, 2014: 197-8; Shaffer 1999). Indeed, as a cooperative organisation that operates in large-scale manufacturing industries, Mondragón is remarkably atypical. A plausible answer is that prevailing institutional environments are generally geared to the prevailing capitalist mode of organisation, thus militating against cooperatives and suppressing their ability to overcome the cooperation/coordination tradeoff (Putterman, 1982; Pagano and Rowthorn, 1996; Everett and Minkler, 1993). Following DiMaggio and Powell's (1983) famous article, I would suggest that this sort of "institutional isomorphism" generally operates through the two aspects of behaviour discussed in Section 2.3: the structural or relational aspect, which affects the options available to individuals, and the cultural or cognitive aspect, which affects the way those options are perceived.

Considering firstly the structural/relational aspect, it has been widely noted that prevailing institutions of finance, law, education, and so on, along with the very frequency of capitalist firms that they support, bias opportunities and incentives against the formation and success of cooperatives (see Webb, 1891; Webb and Webb, 1920). For example, entrepreneurs may be unable to procure finance to start a coop, and could anyway reap greater material rewards by starting a conventional firm (Smith and Rothbaum, 2014: 222; Weitzman, 1984; Podivinsky and Stewart, 2012); cooperatives may struggle to find managers who are capable of working in a democratic firm, and those managers that are eligible will be deterred by the relatively lower managerial pay and autonomy that they offer (Chaves and Sajardo, 2004; Davis, 2001; Spear, 2004); and workers may face severe risks by bundling their wealth with their job, and would anyway be tempted to hire nonmembers or sell their shares to investors (e.g. Ben-Ner 1984, 1988b; Miyazaki, 1984; Vanek, 1977).

The cultural/cognitive aspect, however, is equally critical. Although we saw in Section 2.5 that organisational culture is not fully determined by exogenous cultural traits but rather rooted in organisational structures, isolated cooperatives must vie with the host of "pervasive behaviorshaping institutions" (Rothschild and Whitt, 1986: 67) that propagate an instrumental/transactional approach to work (Pateman, 1970; Blumberg, 1973; Kanter, 1977). This may not only prevent individuals from forming, managing, or working in cooperatives (which they may not even consider in the first place, as the prevailing institutional environment generates a self-reinforcing sense of normality and legitimacy; see Bowles and Gintis, 1976; Everett and Minkler, 1993; Kanter, 1972: 1524), but also force cooperatives into an uphill battle of structural consistency. Indeed, "value-based organisations" have been widely reported to struggle with a kind of 'cultural degeneration', especially as their ideologically-motivated founding members pass the mantle to the next generation (Bruni and Smerilli, 2014; see also Zald and Ash, 1966; Rothschild and Whitt, 1986: 67, 128).

The challenge of achieving structural consistency amidst an institutional environment based on capitalist organisation will be even more challenging for cooperatives if they attempt to implement bureaucratic organisational structures that are normally associated with capitalist firms, even if only for the purpose of achieving coordination. Bureaucracy and democracy are not 
inherently incompatible, as has been repeatedly shown to be true within cooperatives ${ }^{32}$. However, if the day-to-day experience of worker-members (and managers) is no different from that of employees (and managers) in conventional firms, abstract notions of equality and participation substantiated by occasional exercise of voting rights are unlikely to significantly influence their workplace behaviour. Furthermore, a lack of participation in the workplace could initiate a vicious circle that 'spills over' into the realm of governance, as worker-members may become inexperienced and apathetic with regard to democratic processes and increasingly concerned with pecuniary criteria (Ben-Ner, 1984). Managers, meanwhile, may come to be seen as deserving special membership status (Meister, 1984). In what Weber (1930 [1905] termed the "iron cage" and what his apprentice Michels (1962 [1911]) termed the "iron law of oligarchy", bureaucracy could thus expand to the point of effecting "a fundamental change in the authority structure" (Rothschild and Whitt 1986: 113) ${ }^{33}$. In line with the argument of Section 2.4, Weber and Michels also predicted that these obstacles to alleviating the cooperation/coordination trade-off would intensify as the firm expands (see Jones and Kalmi, 2012). Indeed, problems of structural consistency (Whyte and Whyte, 1988, Chapters 9-11; Greenwood and Gonzalez Santos, 1992; Heras-Saizarbitoria, 2014) and bureaucratisation (Bakaikoa, Errasti, and Begiristain, 2004; Cheney, 1999; Storey, Basterretxea, and Salaman 2014) have afflicted Mondragón throughout its rise to prominence.

It has been widely noted that inter-cooperative associations such as the Mondragón group can help alleviate the structural aspect of institutional isomorphism by substituting for mainstream institutions, for instance by providing finance and management training and by redistributing personnel and resources (e.g. Ellerman 1982; Gui, 1984; Basterretxea and Albizu, 2010, 2011; Archibald and Neary, 1983). The cultural aspect provides an additional rationale: inter-cooperative associations may not only contribute to deep-level cooperation directly by providing a common cultural environment (Sacchetti and Tortia, forthcoming), but may also allow individual cooperatives to more effectively pursue deep-level cooperation by alleviating the burden of coordination. This was most apparent in Mondragón's early days, when the 'Entrepreneurial' or 'Business Division' (Division Empresarial) of the cooperative bank (Caja Laboral Popular) assumed the role of not only creating and nurturing new coops, but also coordinating the strategies of existing ones (Whyte and Whyte, 1988, Chapter 8). A particularly relevant policy was to subdivide member cooperatives once they reached some pre-determined maximum size (five-hundred members was the historical benchmark) in order to preserve an organisational culture of deep-level cooperation. The cultural aspect also sheds light on why such associations are not more common: not only might they encounter structural obstacles, as no individual cooperative has an incentive to create them and may anyway be incapable of doing so without some critical number cooperatives already in existence (Joshi and Smith, 2008; Smith and Rothbaum, 2014: 236; Dow and Putterman, 1996: 6770), they may also encounter cultural obstacles, as they may require 'deep-level inter-cooperation' if individual cooperatives are to voluntarily cede autonomy.

\section{$\underline{\text { 4. Conclusions }}$}

\footnotetext{
32 See Varman and Chakrabarti, 2004; Batstone, 1983; Cornforth, 1995; Cornforth et al., 1988; Estrin and Jones, 1992; Hernandez, 2006; Stryjan, 1994; Storey, Basterretxea, and Salaman, 2014.

${ }^{33}$ This problem is also evident in capitalist corporations that separate ownership and management. See Berle and Means, 1932; Jensen and Meckling, 1976; Fama and Jensen, 1983.
} 
This paper firstly argued that the predominant economic theories of the firm neglect the importance of cooperation based on trust and loyalty. While competence-based theories fail to acknowledge that the development and application of productive knowledge requires cooperation, contract-based theories cling to a rigid model of behaviour that does not account for the type of cooperation based on trust and loyalty thus required. In the 'social' theory of the firm subsequently proposed, the paper suggested that this 'deep-level cooperation' may be jeopardised by the bureaucratic organisational structures that are required in order to achieve coordination. Although this effect can be mitigated by an appropriate organisational culture, that organisational culture must be substantiated in organisational structures. A 'distributive dilemma' thus arises whereby power-holders may be required to reform the very organisational structures on which their power is predicated in order to achieve deep-level cooperation. By appreciating the importance of cooperation based on trust and loyalty, this theory of the firm not only improves on but also unifies the two predominant schools.

The paper secondly reconsidered the criticisms levelled against cooperatives by the predominant theories of the firm in light of this theory. Although contract-based theories denigrate cooperatives for failing to achieve cooperation, cooperatives may in fact be better positioned than conventional firms to achieve deep-level cooperation, in which the organisational structures thus required are likely to threaten power-holders. Meanwhile, although competence-based theories imply that cooperatives are incapable of coordinating complex production processes, cooperatives may in fact be more propitiously situated than conventional firms to implement the bureaucratic organisational structures required to achieve coordination without incurring their adverse behavioural effects on cooperation, because worker control can counteract their adverse behavioural effects. In short, cooperatives may have a unique advantage both in achieving deeplevel cooperation and in maintaining deep-level cooperation alongside the bureaucratic organisational structures required for coordination. This advantage, however, may be suppressed by a hostile institutional environment, which biases both the options available to individuals and the way they perceive those options against cooperatives. Inter-cooperative associations can resist this institutional bias, but face their own structural and cultural obstacles.

This is by no means a standard argument. Support for cooperatives from academics, laypeople, and politicians tends to rely either on the notion that workplaces can be dramatically reformed without sacrificing efficiency or on the belief that a sacrifice in efficiency is the price to pay for a more 'humane' economy and society; the underlying assumption in either case is that cooperatives will thrive if and only if bureaucracy is abolished (see Rothschild and Whitt, 1986). Although the theory outlined in this paper suggests that cooperatives will indeed have an advantage in achieving trust and loyalty when complex divisions of labour and hierarchical management systems are not required, its main implication is that cooperatives may in fact have an advantage in implementing complex divisions of labour and hierarchical management systems.

\section{$\underline{\text { References }}$}

Abando, J., Gallertegi, E., \& Rodriguez, J. (2007). The Quality of Management in Basque Companies: Differences between Cooperative and Non-Cooperative Companies. In S. Novkovic \& V. Sena (Eds.), 
Advances in the Economic Analysis of Participatory \& Labor-Managed Firms: Cooperative Firms in Global Markets (Vol. 10, pp. 109-150). Bingley: Emerald.

Abegglen, J. C. (1958). The Japanese Factory: Aspect of Its Social Organisation. Glencoe: Free Press.

Aghion, P., \& Tirole, J. (1997). Formal and Real Authority in Organizations. Journal of Political Economy, 105(1), 1-29.

Akerlof, G. A. (1982). Labor Contracts as Partial Gift Exchange. The Quarterly Journal of Economics, 97(4), 543-569.

Akerlof, G. A., \& Kranton, R. E. (2008). Identity, Supervision, and Work Groups. The American Economic Review, 98(2), 212-217.

Alchian, A. A., \& Demsetz, H. (1972). Production, Information Costs, and Economic Organization. The American Economic Review, 62(5), 777-795.

Aoki, M. (1984). The Co-operative Game Theory of the Firm. Oxford: Clarendon.

Aoki, M. (1988). Information, Incentives, and Bargaining in the Japanese Economy. Cambridge:

Cambridge University Press.

Aoki, M. (1990). Toward an Economic Model of the Japanese Firm. Journal of Economic Literature, 28(1), 1-27.

Archibald, G. C., \& Neary, H. M. (1983). Achieving Pareto-Efficient Outcomes in the Labour-Managed Firm. Vancouver: University of British Columbia, Department of Economics.

Argyres, N. S., \& Liebeskind, J. P. (1999). Contractual Commitments, Bargaining Power, and Governance Inseparability: Incorporating History into Transaction Cost Theory. Academy of Management Review, 24(1), 49-63.

Argyres, N. S., \& Mayer, K. J. (2004). Learning to Contract: Evidence from the Personal Computer Industry. Organization Science, 15(4), 394-410.

Argyris, C. (1964). Integrating the Individual and the Organization. New Brunswick: Transaction.

Azurmendi, J. (1985). El Hombre Cooperativo. Mondragón: Caja Laboral Popular.

Bakaikoa, B., Agirre, A., \& Errasti, A. (2008). The Neo-Schumpeterian Model of Economic Development in the Basque Country: the Role of Social Economy. CIRIEC-España, Revista de Economía Pública, Social y Cooperativa, 62(October), 121-145.

Bakaikoa, B., Errasti, A., \& Begiristain, A. (2004). Governance of the Mondragón Corporación Cooperativa. Annals of Public \& Cooperative Economics, 75(1), 61-87.

Barzel, Y. (1987). The Entrepreneur's Reward for Self-Policing. Economic Inquiry, 25(1), 103-116.

Basterretxea, I., \& Albizu, E. (2010). Management Training as a Source of Perceived Competitive Advantage: the Mondragon Cooperative Group Case. Economic \& Industrial Democracy, 32(2), 199222. 
Basterretxea, I., \& Albizu, E. (2011). Does Training Policy Help to Attract, Retain and Develop Valuable Human Resources? Analysis from the Mondragon Case. In J. DeVaro (Ed.), Advances in the Economic Analysis of Participatory \& Labor-Managed Firms (Vol. 12, pp. 231-260). Bingley: Emerald.

Batstone, E. (1983). Organization and Orientation: a Life Cycle Model of French Cooperatives. Economic \& Industrial Democracy, 4(2), 139-161.

Becker, M. C. (2004). Organizational Routines: a Review of the Literature. Industrial \& Corporate Change, 13(4), 643-678.

Bendix, R. (1963). Work and Authority in Industry: Ideologies of Management in the Course of Industrialization. New York: Harper \& Row.

Ben-Ner, A. (1984). On the Stability of the Cooperative Type of Organization. Journal of Comparative Economics, 8(3), 247-260.

Ben-Ner, A. (1988a). Comparative Empirical Observations on Worker-Owned and Capitalist Firms. International Journal of Industrial Organization, 6(1), 7-31.

Ben-Ner, A. (1988b). The Life Cycle of Worker-Owned Firms in Market Economies: a Theoretical Analysis. Journal of Economic Behavior \& Organization, 10(3), 287-313.

Ben-Ner, A., \& Jones, D. C. (1995). Employee Participation, Ownership, and Productivity: a Theoretical Framework. Industrial Relations, 34(4), 532-554.

Berger, P. L., \& Luckmann, T. (1967). The Social Construction of Reality: a Treatise in the Sociology of Knowledge. London: Penguin Books.

Berle, A. A., \& Means, G. C. (1968 [1932]). The Modern Corporation and Private Property. New York: Harcourt, Brace, \& World.

Blau, P. (1964). Exchange and Power in Social Life. New York: Wiley.

Blau, P. M., \& Scott, W. R. (1962). Formal Organizations: a Comparative Approach. San Francisco: Chandler.

Blauner, B. (1964). Alienation and Freedom: the Factory Worker and His Industry. Chicago: University of Chicago Press.

Blinder, A. S. (Ed.). (1990). Paying for Productivity: a Look at the Evidence. Washington, DC: Brookings Institution Press.

Blood, M. R., \& Hulin, C. L. (1968). Job Enlargement, Individual Differences, and Worker Responses. Psychological Bulletin, 69(1), 41-55.

Blumberg, P. (1973). Industrial Democracy. New York: Schocken.

Bonin, J. P., Jones, D. C., \& Putterman, L. (1993). Theoretical and Empirical Studies of Producer Cooperatives: Will Ever the Twain Meet? Journal of Economic Literature, 31, 1290-1290. 
Bonin, J., \& Putterman, L. (2001). Economics of Cooperation and the Labour-Managed Economy. London: Routledge.

Bowles, S. (1985). The Production Process in a Competitive Economy: Walrasian, Neo-Hobbesian, and Marxian Models. The American Economic Review, 75(1), 16-36.

Bowles, S., \& Gintis, G. (1976). Schooling in Capitalist America: Educational Reform and the Contradictions of Economic Life. New York: Basic Books.

Bradley, K., \& Gelb, A. (1981). Motivation and Control in the Mondragon Experiment. British Journal of Industrial Relations, 19(2), 211-231.

Bradley, K., \& Hill, S. (1987). Quality Circles and Managerial Interests. Industrial Relations, 26(1), 6882.

Braverman, H. (1974). Labor and Monopoly Capital: the Degradation of Work in the Twentieth Century. New York: Monthly Review Press.

Brossard, M., \& Maurice, M. (1976). Is There a Universal Model of Organization Structure? International Studies of Management \& Organization, 6(3), 11-45.

Brown, J. S., \& Duguid, P. (1991). Organizational Learning and Communities-of-Practice: Toward a Unified View of Working, Learning, and Innovation. Organization Science, 2(1), 40-57.

Brown, J. S., \& Duguid, P. (2000). The Social Life of Information. Boston: Harvard Business School Press.

Bruni, L., \& Smerilli, A. (2014). The Economics of Values-Based Organisations: an Introduction. London: Routledge.

Burawoy, M. (1983). Between the Labor Process and the State: the Changing Face of Factory Regimes under Advanced Capitalism. American Sociological Review, 48(5), 587-605.

Cameron, J., \& Pierce, W. D. (1994). Reinforcement, Reward, and Intrinsic Motivation: a MetaAnalysis. Review of Educational Research, 64(3), 363-423.

Carter, R., \& Hodgson, G. M. (2006). The Impact of Empirical Tests of Transaction Cost Economics on the Debate on the Nature of the Firm. Strategic Management Journal, 27(5), 461-476

Chandler, A. D. (1977). The Visible Hand. Cambridge: Harvard University Press.

Chandler, A. D. (1992). Organizational Capabilities and the Economic History of the Industrial Enterprise. Journal of Economic Perspectives, 6(3), 79-100.

Chandler, A. D., \& Daems, H. (1981). Managerial Hierarchies: Comparative Perspectives on the Rise of the Modern Industrial Enterprise. Cambridge: Harvard University Press.

Chang, H.-J. (2008). Bad Samaritans: the Myth of Free Trade and the Secret History of Capitalism. New York: Bloomsbury Press. 
Chang, H.-J., \& Evans, P. (2005). The Role of Institutions in Economic Change. In G. A. Dymski \& S. De Paula (Eds.), Reimagining Growth: Towards a Renewal of Development Theory (pp. 99-140). London: Zed Books.

Chaves, R., \& Sajardo, A. (2004). Social Economy Managers: Between Values and Entrenchment. Annals of Public \& Cooperative Economics, 75(1), 139-161.

Cheney, G. (1999). Values at Work: Employee Participation Meets Market Pressure at Mondragon. Ithaca: Cornell University Press.

Clark, R. (1979). The Japanese Company. New Haven: Yale University Press.

Coase, R. H. (1937). The Nature of the Firm. Economica, 4(16), 386-405.

Cohendet, P., \& Llerena, P. (2003). Routines and Incentives: the Role of Communities in the Firm. Industrial \& Corporate Change, 12(2), 271-297.

Cohendet, P., \& Llerena, P. (2005). A Dual Theory of the Firm between Transactions and Competences: Conceptual Analysis and Empirical Considerations. Revue D'économie Industrielle, 110(1), 175-198.

Cole, R. E. (1971). Japanese Blue Collar, the Changing Tradition. Berkeley: University of California Press.

Cole, R. E. (1979). Work, Mobility, and Participation: a Comparative Study of American and Japanese Industry. Berkeley: University of California Press.

Cornforth, C. (1995). Patterns of Cooperative Management: Beyond the Degeneration Thesis. Economic \& Industrial Democracy, 16(4), 487-523.

Cornforth, C. (2004). The Governance of Cooperatives and Mutual Associations: a Paradox Perspective. Annals of Public \& Cooperative Economics, 75(1), 11-32.

Cornforth, C., Thomas, A., Spear, R. G., \& Lewis, J. M. (1988). Developing Successful Worker Co-ops. London: Sage.

Crozier, M. (1964). The Bureaucratic Phenomenon. Chicago: University of Chicago Press.

Dahlman, C. J. (1979). The Problem of Externality. Journal of Law \& Economics, 22(1), 141-162.

Davis, P. (2001). The Governance of Cooperatives under Competitive Conditions: Issues, Processes and Culture. Corporate Governance, 1(4), 28-39.

Deal, T. E., \& Kennedy, A. A. (2000). Corporate Cultures: the Rites and Rituals of Corporate Life. Cambridge: Perseus Books.

Deci, E. L. (1971). Effects of Externally Mediated Rewards on Intrinsic Motivation. Journal of Personality \& Social Psychology, 18(1), 105-115.

Deci, E. L. (1975). Intrinsic Motivation. New York: Plenum. 
Deci, E. L., Koestner, R., \& Ryan, R. M. (1999a). A Meta-Analytic Review of Experiments Examining the Effects of Extrinsic Rewards on Intrinsic Motivation. Psychological Bulletin, 125(6), 627-668; discussion 692-700.

Deci, E. L., Koestner, R., \& Ryan, R. M. (1999b). The Undermining Effect is a Reality After All - Extrinsic Rewards, Task Interest, and Self-Determination: Reply to Eisenberger, Pierce, and Cameron (1999) and Lepper, Henderlong, and Gingras (1999). Psychological Bulletin, 125(6), 692-700.

Deci, E. L., \& Ryan, R. M. (1985). Intrinsic Motivation and Self-Determination in Human Behavior. New York: Plenum.

DiMaggio, P. J., \& Powell, W. W. (1983). The Iron Cage Revisited: Institutional Isomorphism and Collective Rationality in Organizational Fields. American Sociological Review, 48(2), 147-160.

Dore, R. P. (1973). British Factory, Japanese Factory: the Origins of National Diversity in Industrial Relations. Berkeley: University of California Press.

Dosi, G., \& Marengo, L. (1994). Some Elements of an Evolutionary Theory of Organizational Competences. In R. W. England (Ed.), Evolutionary Concepts in Contemporary Economics (pp. 157178). Ann Arbor: University of Michigan Press.

Dow, G. K. (2003). Governing the Firm: Workers' Control in Theory and Practice. Cambridge: Cambridge University Press.

Dow, G., \& Putterman, L. (1996). Why Capital (Usually) Hires Labor: an Assessment of Proposed Explanations (Discussion Paper No. dp97-03). Department of Economics, Simon Fraser University. Retrieved from http://ideas.repec.org/p/sfu/sfudps/dp97-03.html

Durkheim, E. (1997 [1893]). The Division of Labor in Society. New York: Free Press.

Edwards, R. C. (1979). Contested Terrain: the Transformation of the Workplace in the Twentieth Century. New York: Basic Books.

Edwards, R., Gordon, D. R., \& Reich, M. (1975). Labor Market Segmentation. Lexington: Heath. Egan, D. (1990). Toward a Marxist Theory of Labor-Managed Firms: Breaking the Degeneration Thesis. Review of Radical Political Economics, 22(4), 67-86.

Eisenberger, R., \& Cameron, J. (1996). Detrimental Effects of Reward: Reality or Myth? American Psychologist, 51(11), 1153-1166.

Ellerman, D. P. (1982). The Socialization of Entrepreneurship: the Empresarial Division of the Caja Laboral Popular. Sommerville: Industrial Cooperative Association.

Estrin, S., \& Jones, D. C. (1992). The Viability of Employee-Owned Firms: Evidence from France. Industrial \& Labor Relations Review, 45(2), 323-338.

Estrin, S., Jones, D. C., \& Svejnar, J. (1987). The Productivity Effects of Worker Participation: Producer Cooperatives in Western Economies. Journal of Comparative Economics, 11(1), 40-61. 
Eswaran, M., \& Kotwal, A. (1984). The Moral Hazard of Budget-Breaking. The RAND Journal of Economics, 15(4), 578-581.

Everett, M. J., \& Minkler, L. (1993). Evolution and Organisational Choice in Nineteenth-Century Britain. Cambridge Journal of Economics, 17(1), 51-62.

Fama, E. F. (1980). Agency Problems and the Theory of the Firm. Journal of Political Economy, 88(2), 288-307.

Fama, E. F., \& Jensen, M. C. (1983). Separation of Ownership and Control. Journal of Law \& Economics, 26(2), 301-325.

FitzRoy, F. R., \& Kraft, K. (1986). Profitability and Profit-Sharing. The Journal of Industrial Economics, 35(2), 113-130.

Foss, N. J. (2003). Bounded Rationality in the Economics of Organization: "Much Cited and Little Used". Journal of Economic Psychology, 24(2), 245-264.

Foss, N. J. (1993). Theories of the Firm: Contractual and Competence Perspectives. Journal of Evolutionary Economics, 3(2), 127-144.

Foss, N. J. (1997). The Classical Theory of Production and the Capabilities View of the Firm. Journal of Economic Studies, 24(5), 307-323.

Fox, A. (1974). Beyond Contract: Work Power and Trust Relations. London: Faber \& Faber.

Frohlich, N., Godard, J., Oppenheimer, J. A., \& Starke, F. A. (1998). Employee versus ConventionallyOwned and Controlled Firms: an Experimental Analysis. Managerial \& Decision Economics, 19(4-5), 311-326.

Fucini, J. J., \& Fucini, S. (1990). Working for the Japanese: Inside Mazda's American Auto Plant. New York: Free Press.

Gallie, D. (1978). In Search of the New Working Class: Automation and Social Integration within the Capitalist Enterprise. London: Cambridge University Press.

Gherardi, S., \& Masiero, A. (1990). Solidarty as a Networking Skill and a Trust Relation: its Implications for Cooperative Development. Economic \& Industrial Democracy, 11(4), 553-574.

Gjerding, A. N. (1992). Work Organisation and the Innovation Design Dilemma. In B.-Å. Lundvall (Ed.), National Systems of Innovation: Towards a Theory of Innovation and Interactive Learning (pp. 95-115). London: Pinter.

Goffin, K., \& Koners, U. (2011). Tacit Knowledge, Lessons Learnt, and New Product Development. Journal of Product Innovation Management, 28(2), 300-318.

Gouldner, A. (1954). Patterns of Industrial Bureaucracy. Glencoe: Free Press.

Greenwood, D. J., \& Gonzalez Santos, J. L. (1992). Industrial Democracy as Process: Participatory Action Research in the Fagor Cooperative Group of Mondragón. Stockholm: Van Gorcum. 
Grenier, G. J. (1988). Inhuman Relations: Quality Circles and Anti-Unionism in American Industry. Philadelphia: Temple University Press.

Grossman, S. J., \& Hart, O. D. (1986). The Costs and Benefits of Ownership: a Theory of Vertical and Lateral Integration. Journal of Political Economy, 94(4), 691.

Gui, B. (1984). Basque versus Illyrian Labor-managed Firms: the Problem of Property Rights. Journal of Comparative Economics, 8(2), 168-181.

Hanappi-Egger, E. (1996). The Hidden Trade-offs of Cooperative Work: an Empirical Study. Organization Studies, 17(6), 1011-1022.

Hansmann, H. (1988). Ownership of the Firm. Journal of Law, Economics \& Organization, 4(2), 267304.

Hansmann, H. (1990). When Does Worker Ownership Work? ESOPs, Law Firms, Codetermination, and Economic Democracy. The Yale Law Journal, 99(8), 1749-1816.

Hansmann, H. (1996). The Ownership of Enterprise. Cambridge: Belknap Press.

Hart, O. (1989). An Economist's Perspective on the Theory of the Firm. Columbia Law Review, 89(7), 1757-1774.

Hart, O., \& Moore, J. (1990). Property Rights and the Nature of the Firm. Journal of Political Economy, 98(6), 1119-58.

Heras-Saizarbitoria, I. (2014). The Ties that Bind? Exploring the Basic Principles of Worker-Owned Organizations in Practice. Organization, 21(5), 645-665.

Hernandez, S. (2006). Striving for Control: Democracy and Oligarchy at a Mexican Cooperative. Economic \& Industrial Democracy, 27(2), 105-135.

Hill, F. M. (1986). Quality Circles in the UK: a Longitudinal Study. Personnel Review, 15(3), 25-34.

Hodgson, G. M. (1999). Evolution and Institutions: on Evolutionary Economics and the Evolution of Economics. Cheltenham: Edward Elgar.

Hodgson, G. M. (2002). Reconstitutive Downward Causation: Social Structure and the Development of Individual Agency. In E. Fullbrook (Ed.), Intersubjectivity in Economics: Agents and Structures (pp. 159-180). London: Routledge.

Hofstede, G. H. (2001). Culture's Consequences: Comparing Values, Behaviors, Institutions, and Organizations across Nations (2nd ed.). Thousand Oaks: Sage.

Holmstrom, B. (1982). Moral Hazard in Teams. The Bell Journal of Economics, 13(2), 324-340.

Indik, B. P. (1963). Some Effects of Organization Size on Member Attitudes and Behavior. Human Relations, 16(4), 369-384.

Ingham, G. K. (1970). Size of Industrial Organization and Worker Behavior. London: Cambridge University Press. 
Islam, G., \& Zyphur, M. J. (2009). Rituals in Organizations: a Review and Expansion of Current Theory. Group \& Organization Management, 34(1), 114-139.

Jacobides, M. G., \& Winter, S. G. (2005). The Co-evolution of Capabilities and Transaction Costs: Explaining the Institutional Structure of Production. Strategic Management Journal, 26(5), 395-413. Jensen, M. C., \& Meckling, W. H. (1976). Theory of the Firm: Managerial Behavior, Agency Costs and Ownership Structure. Journal of Financial Economics, 3(4), 305-360.

Jensen, M. C., \& Meckling, W. H. (1979). Rights and Production Functions: an Application to LaborManaged Firms and Codetermination. The Journal of Business, 52(4), 469-506.

Jones, D. C., \& Kalmi, P. (2014). Economies of Scale versus Participation: a Co-operative Dilemma? Journal of Entrepreneurial and Organizational Diversity, 1(1), 37-64.

Joshi, S., \& Smith, S. C. (2008). Endogenous Formation of Coops and Cooperative Leagues. Journal of Economic Behavior \& Organization, 68(1), 217-233.

Jossa, B. (2005). Marx, Marxism and the Cooperative Movement. Cambridge Journal of Economics, 29(1), 3-18.

Kanter, R. M. (1972). Commitment and Community. Cambridge: Harvard University Press.

Kanter, R. M. (1977). Men and Women of the Corporation. New York: Basic Books.

Kasmir, S. (1996). The Myth of Mondragón: Cooperatives, Politics, and Working-Class Life in a Basque Town. Albany: State University of New York Press.

Kaswan, M. J. (2013). Democratic Differences: How Type of Ownership Affects Workplace Democracy and its Broader Social Effects. In D. Kruse (Ed.), Advances in the Economic Analysis of Participatory \& Labor-Managed Firms: Sharing Ownership, Profits, and Decision-Making in the 21st Century (Vol. 14, pp. 261-294). Bingley: Emerald.

Kerr, C., \& Siegel, A. (1954). The Interindustry Propensity to Strike. In Industrial Conflict. New York: McGraw-Hill.

Klein, B., Crawford, R. G., \& Alchian, A. A. (1978). Vertical Integration, Appropriable Rents, and the Competitive Contracting Process. Journal of Law \& Economics, 21(2), 297-326.

Knight, F. H. (1921). Risk, Uncertainty, and Profit. Boston: Houghton Mifflin.

Knights, D., \& Willmott, H. C. (1987). Organizational Culture as Management Strategy. International Studies of Management \& Organization, 17(3), 40-63.

Knights, D., \& Willmott, H. C. (1989). Power and Subjectivity at Work: from Degradation to Subjugation in Work Relations. Sociology, 23(4), 535-558.

Kogut, B., \& Zander, U. (1992). Knowledge of the Firm, Combinative Capabilities, and the Replication of Technology. Organization Science, 3(3), 383-397. 
Kogut, B., \& Zander, U. (1996). What Firms Do? Coordination, Identity, and Learning. Organization Science, 7(5), 502-518.

Langlois, R. N. (1992). Transaction-cost Economics in Real Time. Industrial \& Corporate Change, 1(1), 99-127.

Langlois, R. N. (2007). The Dynamics of Industrial Capitalism: Schumpeter, Chandler, and the New Economy. London: Routledge.

Langlois, R. N., \& Cosgel, M. M. (1993). Frank Knight on Risk, Uncertainty, and the Firm: a New Interpretation. Economic Inquiry, 31(3), 456-465.

Langlois, R. N., \& Foss, N. J. (1999). Capabilities and Governance: the Rebirth of Production in the Theory of Economic Organization. Kyklos, 52(2), 201-18.

Lave, J., \& Wenger, E. (1991). Situated Learning: Legitimate Peripheral Participation. Cambridge: Cambridge University Press.

Lincoln, J. R., \& Kalleberg, A. L. (1990). Culture, Control, and Commitment: a Study of Work Organization and Work Attitudes in the United States and Japan. Cambridge: Cambridge University Press.

Logan, C. (1979). The Mondragón Cooperative Model: a Critical Appraisal. Public Enterprise, 16, 7-8.

Lopez, U., Lopez, S., \& Larrañaga, I. (2009). Innovation in Industrial Cooperatives: Special Features and Potential of the Mondragon Model. International Journal of Technology Management \& Sustainable Development, 8(1), 39-56.

MacLeod, G. (2000). From Mondragon to America: Experiments in Community Economic Development (3rd ed.). Sydney: University College of Cape Breton Press.

Madhok, A. (2002). Reassessing the Fundamentals and Beyond: Ronald Coase, the Transaction Cost and Resource-based Theories of the Firm and the Institutional Structure of Production. Strategic Management Journal, 23(6), 535-550.

Mahoney, J. T. (1992). The Choice of Organizational Form: Vertical Financial Ownership versus Other Methods of Vertical Integration. Strategic Management Journal, 13(8), 559-584.

March, J. G., \& Simon, H. A. (1958). Organizations. Oxford: Wiley.

Marglin, S. A. (1974). What Do Bosses Do? The Origins and Functions of Hierarchy in Capitalist Production. Review of Radical Political Economics, 6(2), 60-112.

Marx, K. (1864). Inaugural Address and Provisional Rules of the International Working Men's Association, along with the "General Rules." London: International Working Men's Association. Retrieved from https://www.marxists.org/archive/marx/works/1864/10/27.htm

Marx, K. (1867). Instructions for the Delegates of the Provisional General Council. International Courier, 6/7. Retrieved from https://www.marxists.org/archive/marx/works/1866/08/instructions.htm\#05 
Marx, K. (1959 [1894]). Capital, Volume III. (Marx, K. \& Engels, F., Eds.). New York: International. Retrieved from http://www.marxists.org/archive/marx/works/1894-c3/

Marx, K. (1970 [1875]). Critique of the Gotha Programme. Moscow, Russia: Progress. Retrieved from https://www.marxists.org/archive/marx/works/1875/gotha/index.htm

Matrix Evidence. (2010). The Employee Ownership Effect: a Review of the Evidence. Employee Ownership Association. Retrieved from

http://eoa.fredsite.co.uk/wpcontent/uploads/The_employee_ownership_effect_a_review_of_the_e vidence.pdf

Maurice, M., Sorge, A., \& Warner, M. (1980). Societal Differences in Organizing Manufacturing Units: a Comparison of France, West Germany, and Great Britain. International Studies of Management \& Organization, 10(4), 74-100.

Meister, A. (1984). Participation, Associations, Development, and Change. New Brunswick: Transaction.

Michels, R. (1962 [1911]). Political Parties: a Sociological Study of the Oligarchical Tendencies of Modern Democracy. New York: Collier Books.

Miyazaki, H. (1984). On Success and Dissolution of the Labor-Managed Firm in the Capitalist Economy. Journal of Political Economy, 92(5), 909-931.

Mondragón Corporation. (2012). Annual Report 2012. Retrieved from http://www.mondragoncorporation.com/wp-content/themes/builder/informe-anual2013/pdf/en/annual-report-2012.pdf

Monteverde, K., \& Teece, D. J. (1982). Supplier Switching Costs and Vertical Integration in the Automobile Industry. Bell Journal of Economics, 13(1), 206-213.

Moore, J. (1992). The Firm as a Collection of Assets. European Economic Review, 36(2-3), 493-507.

Morishima, M. (1982). Why Has Japan Succeeded? Western Technology and the Japanese Ethos. Cambridge: Cambridge University Press.

Moschandreas, M. (1997). The Role of Opportunism in Transaction Cost Economics. Journal of Economic Issues, 31(1), 39-57.

Nakane, C. (1970). Japanese Society. London: Pelican.

Nelson, R. R., \& Winter, S. G. (1982). An Evolutionary Theory of Economic Change. Cambridge: Harvard University Press.

Nooteboom, B. (1992). Towards a Dynamic Theory of Transactions. Journal of Evolutionary Economics, 2(4), 281-299.

Nooteboom, B. (2009). A Cognitive Theory of the Firm: Learning, Governance and Dynamic Capabilities. London: Edward Elgar. 
Oakeshott, R., Campbell, A., Norman, G., \& Keen, C. (1977). Worker-Owners: the Mondragón Achievement: the Caja Laboral Popular and the Mondragón Co-operatives in the Basque Provinces of Spain. London: Anglo-German Foundation for the Study of Industrial Society.

Osterloh, M., \& Frey, B. S. (2000). Motivation, Knowledge Transfer, and Organizational Forms. Organization Science, 11(5), 538-550.

Ouchi, W. G. (1980). Markets, Bureaucracies, and Clans. Administrative Science Quarterly, 25(1), 129-141.

Pagano, U. (1991). Property Rights, Asset Specificity, and the Division of Labour under Alternative Capitalist Relations. Cambridge Journal of Economics 15(3), 315-342.

Pagano, U., \& Rowthorn, R. E. (Eds.). (1996). The Competitive Selection of Democratic Firms in a World of Self-Sustaining Institutions. In U. Pagano \& R. E. Rowthorn (Eds.), Democracy and Efficiency in the Economic Enterprise (pp. 116-145). London: Routledge.

Paranque, B., \& Willmott, H. C. (2014). Cooperatives - Saviors or Gravediggers of Capitalism? Critical Performativity and the John Lewis Partnership. Organization, 21(5), 604-625.

Parker, M. (2002). Against Management: Organisation in the Age of Managerialism. Oxford: Polity. Parker, M., \& Slaughter, J. (1988). Choosing Sides: Unions and the Team Concept. Boston: South End Press.

Parsons, T., \& Smelser, N. J. (1956). Economy and Society: a Study in the Integration of Economic and Social Theory. London: Routledge.

Pateman, C. (1970). Participation and Democratic Theory. Cambridge: Cambridge University Press.

Penrose, E. T. (1959). The Theory of the Growth of the Firm. Oxford: Oxford University Press.

Phillips, R. J. (1985). Marx, the Classical Firm, and Economic Planning. Journal of Post Keynesian Economics, 8(2), 266-276.

Podivinsky, J. M., \& Stewart, G. (2012). On the Choice between Capitalist and Labour-Managed Production: Evidence from a Panel of Entrants into UK Manufacturing Industries. In A. Bryson (Ed.), Advances in the Economic Analysis of Participatory \& Labor-Managed Firms (Vol. 13, pp. 77-95). Bingley: Emerald.

Polanyi, M. (1958). Personal Knowledge: Towards a Post-Critical Philosophy. Chicago: University of Chicago Press.

Polanyi, M. (1966). The Tacit Dimension. London: Routledge.

Putterman, L. (1982). Some Behavioral Perspectives on the Dominance of Hierarchical over Democratic Forms of Enterprise. Journal of Economic Behavior \& Organization, 3(2-3), 139-160.

Putterman, L. (1984). On Some Recent Explanations of Why Capital Hires Labor. Economic Inquiry, 22(2), 171-187. 
Ravasi, D., \& Schultz, M. (2006). Responding to Organizational Identity Threats: Exploring the Role of Organizational Culture. Academy of Management Journal, 49(3), 433-458.

Reinert, E. S. (2007) How Rich Countries Got Rich ... and Why Poor Countries Stay Poor. London: Constable.

Rinehart, J., Huxley, C., \& Robertson, D. (1997). Just Another Car Factory? Lean Production and its Discontents. Ithaca: Cornell University Press.

Riordan, M. H., \& Williamson, O. E. (1985). Asset Specificity and Economic Organization. International Journal of Industrial Organization, 3(4), 365-378.

Rohlen, T. P. (1974). For Harmony and Strength: Japanese White-Collar Organization in Anthropological Perspective. Berkeley: University of California Press.

Rothschild, J., \& Whitt, J. A. (1986). The Cooperative Workplace: Potentials and Dilemmas of Organisational Democracy and Participation. Cambridge: Cambridge University Press.

Rummel, A., \& Feinberg, R. (1988). Cognitive Evaluation Theory: a Meta-analytic Review of the Literature. Social Behavior \& Personality, 16(2), 147-164.

Russell, R. (1985). Employee Ownership and Internal Governance. Journal of Economic Behavior \& Organization, 6(3), 217-241.

Sacchetti, S., \& Tortia, E. (forthcoming). The Extended Governance of Cooperative Firms: Inter-firm Coordination and Consistency of Values. Annals of Public \& Cooperative Economics, 86(2).

Salancik, G., \& Pfeffer, J. (1977). Who Gets Power - and How They Hold on to It: a Strategic Contingency Model of Power. Organizational Dynamics, 5(3), 3-21.

Schein, E. H. (1992). Organizational Culture and Leadership. San Francisco: Wiley.

Schmidt, F. L., \& Hunter, J. E. (1993). Tacit Knowledge, Practical Intelligence, General Mental Ability, and Job Knowledge. Current Directions in Psychological Science, 2(1), 8-9.

Shaffer, J. (1997). Historical Dictionary of the Co-operative Movement. Bern: Peter Lang.

Shorter, E., \& Tilly, C. (1974). Strikes in France, 1830-1968. London: Cambridge University Press.

Simmel, G. (1964 [1917]). The Sociology of Georg Simmel. (K. Wolff, Trans.). Glencoe: Free Press.

Simon, H. A. (1957). Models of Man: Social and Rational; Mathematical Essays on Rational Human Behavior in a Social Setting. Oxford: Wiley.

Simon, H. A. (1962). The Architecture of Complexity. Proceedings of the American Philosophical Society, 106(6), 467-482.

Simon, H. A. (1976). From Substantive to Procedural Rationality. In S. J. Latsis (Ed.), Method and Appraisal in Economics (pp. 129-161). Cheltenham: Cambridge University Press.

Simon, H. A. (1991). Organizations and Markets. Journal of Economic Perspectives, 5(2), 25-44. 
Smircich, L. (1983). Concepts of Culture and Organizational Analysis. Administrative Science Quarterly, 339-358.

Smith, A. (1904 [1776]). An Inquiry into the Nature and Causes of the Wealth of Nations (5th ed.). London: Methuen \& Co. Retrieved from http://www.econlib.org/library/Smith/smWNCover.html

Smith, A. (1790 [1759]). The Theory of Moral Sentiments (6th ed.). London: A. Millar. Retrieved from http://www.econlib.org/library/Smith/smMS1.html

Smith, S. C., \& Rothbaum, J. (2014). Co-operatives in a Global Economy: Key Issues, Recent Trends and Potential for Development. In S. Novkovic \& T. Webb (Eds.), Co-operatives in a Post-Growth Era: Creating Co-operative Economics (pp. 221-241). Black Point: Fernwood, Zed Books.

Spear, R. (2004). Governance in Democratic Member-Based Organisations. Annals of Public \& Cooperative Economics, 75(1), 33-60.

Storey, J., Basterretxea, I., \& Salaman, G. (2014). Managing and Resisting "Degeneration" in Employee-Owned Businesses: a Comparative Study of Two Large Retailers in Spain and the United Kingdom. Organization, 21(5), 626-644.

Stryjan, Y. (1994). Understanding Cooperatives: the Reproduction Perspective. Annals of Public \& Cooperative Economics, 65(1), 59-80.

Tang, S.-H., \& Hall, V. C. (1995). The Overjustification Effect: a Meta-analysis. Applied Cognitive Psychology, 9(5), 365-404.

Teece, D. J. (1982). Towards an Economic Theory of the Multiproduct Firm. Journal of Economic Behavior \& Organization, 3(1), 39-63.

Teece, D. J. (1986). Profiting from Technological Innovation: Implications for Integration, Collaboration, Licensing and Public Policy. Research Policy, 15(6), 285-305.

Teece, D., \& Pisano, G. (1994). The Dynamic Capabilities of Firms: an Introduction. Industrial \& Corporate Change, 3(3), 537-556.

Thomas, H., \& Logan, C. (1982). Mondragon: an Economic Analysis. Winchester: Allen \& Unwin.

Turnbull, S. (1995). Case Study: Innovations in Corporate Governance: the Mondragón Experience. Corporate Governance: An International Review, 3(3), 167-180.

Turner, A. N., \& Lawrence, P. R. (1965). Industrial Jobs and the Workers: an Investigation of Response to Task Attributes. Cambridge: Harvard University, Division of Research, Graduate School of Business Administration.

Urabe, K., Child, J., \& Kagono, T. (Eds.). (1988). Innovation and Management: International Comparisons. Berlin: Walter de Gruyter.

Valentinov, V. L. (2004). Toward a Social Capital Theory of Cooperative Organisation. Journal of Cooperative Studies, 37(3), 5-20. 
Valentinov, V. (2007). Why Are Cooperatives Important in Agriculture? An Organizational Economics Perspective. Journal of Institutional Economics, 3(1), 55-69.

Vanek, J. (1977). The Labor-Managed Economy: Essays by Jaroslav Vanek. Ithaca: Cornell University Press.

Varman, R., \& Chakrabarti, M. (2004). Contradictions of Democracy in a Workers' Cooperative. Organization Studies, 25(2), 183-208.

Vogel, E. F. (Ed.). (1975). Modern Japanese Organization and Decision-Making. Berkeley: University of California Press.

Vogt, W. (1996). Capitalist versus Liberal Firm and Economy: Outline of a Theory. In U. Pagano \& R. E. Rowthorn (Eds.), Democracy and Efficiency in the Economic Enterprise (pp. 39-63). London:

Routledge.

Vroom, V. H. (1964). Work and Motivation. San Francisco: Jossey-Bass.

Walker, G., \& Weber, D. (1984). A Transaction Cost Approach to Make-or-Buy Decisions.

Administrative Science Quarterly, 29(3), 373-391.

Webb, B. (1891). The Co-operative Movement in Great Britain. London: Swan Sonnenschein \& Co.

Webb, S. J., \& Webb, B. P. (1920). A Constitution for the Socialist Commonwealth of Great Britain. London: Longmans, Green \& Co.

Weber, M. (1930 [1905]). The Protestant Ethic and the Spirit of Capitalism. (T. Parsons \& A. Giddens, Trans.). London: Unwin Hyman.

Weber, M. (1978 [1922]). Law in Economy and Society. (G. Roth \& C. Wittich, Eds.). Berkeley: University of California Press.

Weitzman, M. (1984). The Share Economy: Conquering Stagflation. Cambridge: Harvard University Press.

Weitzman, M., \& Kruse, D. (1990). Profit Sharing and Productivity. In A. S. Blinder (Ed.), Paying for Productivity: A Look at the Evidence (pp. 95-141). Washington, DC: Brookings Institution Press.

Wenger, E. (1998). Communities of Practice: Learning, Meaning, and Identity. Cambridge: Cambridge University Press.

Wenger, E., McDermott, R. A., \& Snyder, W. (2002). Cultivating Communities of Practice: a Guide to Managing Knowledge. Boston: Harvard Business School Press.

Whyte, W. F., \& Whyte, K. K. (1988). Making Mondragon: the Growth and Dynamics of the Worker Cooperative Complex. Ithaca: Cornell University Press.

Wiersma, U. J. (1992). The Effects of Extrinsic Rrewards in Intrinsic Motivation: a Meta-analysis. Journal of Occupational \& Organizational Psychology, 65(2), 101-114. 
Williamson, O. E. (1975). Markets and Hierarchies: Analysis and Antitrust Implications. New York: Free Press.

Williamson, O. E. (1985). The Economic Institutions of Capitalism. New York: Free Press.

Williamson, O. E. (1996). The Mechanisms of Governance. New York: Oxford University Press.

Willmott, H. C. (1993). Strength Is Ignorance; Slavery Is Freedom: Managing Culture in Modern Organizations. Journal of Management Studies, 30(4), 515-552.

Winter, S. G. (1982). An Essay on the Theory of Production. In S. H. Hymans (Ed.), Economics and the World around It (pp. 55-91). Ann Arbor: University of Michigan Press.

Winter, S. G. (1988). On Coase, Competence, and the Corporation. Journal of Law, Economics \& Organization, 4(1), 163-180.

World Co-operative Monitor. (2013). Exploring the Co-operative Economy. International Cooperative Alliance / Euricse. Retrieved from http://euricse.eu/sites/euricse.eu/files/wcm2013_web_0.pdf Yoshino, M. Y. (1971). Japan's Managerial System: Tradition and Innovation. Cambridge: MIT Press. Zald, M. N., \& Ash, R. (1966). Social Movement Organizations: Growth, Decay and Change. Social Forces, 44(3), 327-341.

Zamagni, V. N. (2014). The Co-operative Enterprise: a Valid Alternative for a Balanced Society. In S. Novkovic \& T. Webb (Eds.), Co-operatives in a Post-Growth Era: Creating Co-operative Economics (pp. 194-209). Black Point: Fernwood, Zed Books. 
